\title{
Szkolnictwo mniejszości ukraińskiej w Polsce i polskiej mniejszości na Ukrainie
}

Słowa kluczowe: szkolnictwo, mniejszości narodowe, Ukraina, Polska Keywords: education, a national minority, Ukraine, Poland

Education of the Ukrainian minority in Poland and of the Polish minority in Ukraine

The article discusses the situation of the Ukrainian minority in Poland and the Polish minority in Ukraine with special emphasis on education. The author made a comparative analysis showing the policy of the authorities towards the education, the state numbers and the problems they intend to overcome the minority.

Stosunek władz państwowych do mniejszości narodowych, stopień zaangażowania w ich rozwój i ochronę, czy wysokość środków przekazywanych na ich działalność są ważnymi czynnikami definiującymi politykę prowadzoną przez państwo wobec kraju mniejszości, wobec przedstawicieli własnej grupy narodowościowej, a także w zakresie szeroko rozumianej działalności oświatowej. Niniejszy artykuł podejmuje problematykę jednego z elementów tej polityki, tj. kwestię szkolnictwa mniejszości ukraińskiej w Polsce i polskiej mniejszości na Ukrainie. Zagadnienie kształtu oświaty obu mniejszości jest kwestią o tyle ważną, co skomplikowaną, która ze względu na długą wspólną historię oraz liczebność przedstawicieli wymaga opracowania i ciągłej aktualizacji. Celem artykułu jest wstępne zarysowanie aktualnego stanu obu systemów oświaty wobec mniejszości oraz wskazanie głównych uwarunkowań i prawidłowości określających ten stan oraz wyzwania i potrzeby. Badanie obejmuje - w przypadku Polski okres 
od przemian politycznych 1989 roku; w przypadku Ukrainy - lata od odzyskania niepodległości w 1991 r. aż po rok szkolny 2014/2015. Zarówno Polska, jak i Ukraina dążą, by za pomocą aktów prawnych realnie polepszać status własnych mniejszości za granicą, zatem ważnym zagadnieniem badawczym jest ustalenie, jakie warunki oba kraje zapewniają mniejszościom zamieszkującym na ich terytorium.

\section{Polska i ukraińska definicja pojęcia „mniejszość narodowa"}

W Polsce Ustawa o mniejszościach narodowych i etnicznych oraz o języku regionalnym z 2005 r. opisuje pojęcie „mniejszość narodowa" w następujący sposób: Mniejszościa narodowa (...) jest grupa obywateli polskich, która spetnia łacznie następujace warunki: jest mniej liczebna od pozostałej części ludności Rzeczypospolitej Polskiej; w sposób istotny odróżnia się od pozostatych obywateli językiem, kultura lub tradycja; dązy do zachowania swojego języka, kultury lub tradycji; ma świadomość własnej, historycznej wspólnoty narodowej i jest ukierunkowana na jej wyrażanie i ochronę; jej przodkowie zamieszkiwali obecne terytorium Rzeczypospolitej Polskiej od co najmniej 100 lat; utożsamia się z narodem zorganizowanym we własnym państwie (w odróżnieniu od mniejszości etnicznej, która nie ma odniesienia do zewnętrznej państwowości) ${ }^{1}$. W rozumieniu powyższej ustawy w Polsce żyje 9 mniejszości narodowych.

Najwyższym aktem prawnym, który dotyczy tematu mniejszości narodowych na Ukrainie jest Konstytucja z 28 czerwca 1996 r. Artykuł 11 głosi iż państwo popiera konsolidację i rozwój narodu ukraińskiego, jego historyczna świadomość, tradycję i kulture, a także rozwój etniczny, kulturowy, językowy i religijny tożsamości wszystkich rdzennych ludów i mniejszości narodowych Ukrainy². System ukra-

\footnotetext{
${ }^{1}$ Ustawa o mniejszościach narodowych $i$ etnicznych oraz o języku regionalnym z dnia 6 stycznia 2005 r. (Dz.U. 2005 nr 17 poz. 141), http://isap.sejm.gov.pl/DetailsServlet?id=WDU20050170141, [dostęp: 12.02.2016].

${ }^{2}$ Konstytucja Ukrainy, Rozdziat I..., op.cit., art. 11, [dostęp: 5.03.2016].
} 
ińskiego ustawodawstwa gwarantuje im równość względem prawa, swobodę polityczną i religijną oraz, mimo że językiem państwowym jest ukraiński, członkowie mniejszości mogą posługiwać się własnym językiem, co w szczególności sytuacji socjalistycznej Ukrainy zostało opisane w art. 10: na Ukrainie gwarantuje się swobodny rozwój, używanie i ochrone języka rosyjskiego oraz innych języków mniejszości narodowych Ukrainy ${ }^{3}$.

Definicję mniejszości narodowej doprecyzowuje Ustawa o mniejszościach narodowych na Ukrainie z 1992 r., zgodnie z którą na Ukrainie [mniejszość narodowa] - to przedstawiciele wszystkich narodów, $z$ wyjątkiem rdzennego ${ }^{4}$. Ponadto mniejszość narodowa w ustawodawstwie ukraińskim ma następujące cechy: to obywatele Ukrainy, ale nie narodowości ukraińskiej, których wyróżnia poczucie tożsamości narodowej i wspólnoty we własnej grupie ${ }^{5}$. Z powyższych zapisów wynika, iż czynnikiem, który decyduje o przyznaniu statusu mniejszości narodowej na Ukrainie jest obywatelstwo, bowiem zgodnie z art. 4 Konstytucji: Na Ukrainie przyznaje się tylko jedno obywatelstwo ${ }^{6}$.

Według Narodowego Spisu Ludności przeprowadzonego w 2001 r. na Ukrainie kraj zamieszkiwany jest przez 130 różnych narodowości.

\section{Liczebność i rozmieszczenie obu mniejszości na terenie Polski i Ukrainy}

Powstanie mniejszości polskiej na Ukrainie i mniejszości ukraińskiej w Polsce jest konsekwencją wspólnej historii obu państw, której początek datowany jest na 981 r., kiedy rozpoczął się konflikt

\footnotetext{
${ }^{3}$ Ibid.

${ }^{4}$ Olszański T.A., Problem językowy.., op.cit., s. 45.

${ }^{5}$ Potapenko K., Cudzoziemcy i mniejszości narodowe na Ukrainie i w Polsce, http:// www.allerhand.pl/docs/granty/Mniejszosci_narodowe_na_Ukrainie_i_w_Polsceraport_PL.pdf, [dostęp: 12.03.2016].

${ }^{6}$ Konstytucja Ukrainy, Rozdziat I..., op.cit., art. 11, [dostęp 5.03.2016].
} 
zbrojny między Polską a Rusią Kijowską o Grody Czerwieńskie ${ }^{7}$. Ukraińcy są obecnie jedną z dziewięciu ustawowo uznanych mniejszości narodowych w Polsce, drugą pod względem liczebności (po Niemcach). Zgodnie z danymi narodowego spisu powszechnego z 2004 r., narodowość ukraińską zadeklarowało 51001 osób, z czego ponad połowa jako jedyną (27 630). Diaspora ukraińska w Polsce, w przeciwieństwie do np. Litwinów, nie tworzy wspólnot na terenach graniczących z ziemiami jej narodu, lecz rozproszyła się w Polsce zachodniej i północnej ${ }^{8}$.

Na Ukrainie jak dotąd jedynym przeprowadzonym po rozpadzie ZSRR, a zarazem najnowszym spisem powszechnym ludności, jest spis z 2001 r. Poprzedza go jedynie spis z 1989 r. Zgodnie z nimi polska mniejszość jest jedną ze 130 narodowości zamieszkujących tereny Ukrainy i liczy ponad 144 tys. Polaków ${ }^{9}$. Według nieoficjalnych danych liczba ta może wynosić nawet 2 miliony. Polacy, w przeciwieństwie do polskiej mniejszości na Litwie i Białorusi, nie zamieszkują najliczniej terenów dawnej Rzeczpospolitej. Konsekwencją repatriacji międzywojennej był odpływ polskiej ludności z obwodów: lwowskiego, tarnopolskiego, stanisławowskiego czy wołyńskiego, choć nadal liczna jej grupa żyje na terenach wschodnich od rzeki Zbrucz, czyli przede wszystkim w obwodzie żytomierskim oraz chmielnickim. W 2001 r. obwód żytomierski zamieszkiwało 49 tys. Polaków, chmielnicki - 23 tys., zaś lwowski - 18,9 tys. W samej stolicy Ukrainy, Kijowie, ok. 7 tys. obywateli zadeklarowało polskie pochodzenie ${ }^{10}$.

\footnotetext{
${ }^{7}$ Paszkiewicz H., Początek Rusi, Kraków 1996, s. 87-118.

${ }^{8}$ Przynależność narodowo-etniczna ludności-wyniki spisu ludności i mieszkań 2011, http://stat.gov.pl/cps/rde/xbcr/gus/Przynaleznosc_narodowo-etniczna_w_2011_ NSP.pdf, [dostęp: 8.03.2016].

${ }^{9}$ Kałakura J., Polacy na Ukrainie po rozpadzie ZSRS, http://kresy.wm.pl/226663,Polacy-na-Ukrainie-po-rozpadzie-ZSRS.html, [dostęp: 12.02.2016].

${ }^{10}$ Polacy na Ukrainie - wg spisu ludności w 2001 r., http://wspolnotapolska.org.pl/ polonia_w_opracowaniach/20.html, [dostęp: 20.02.2016].
} 


\section{Problematyka szkolnictwa mniejszości ukraińskiej w Polsce}

a) Akty prawne regulujące politykę językową wobec mniejszości ukraińskiej w Polsce

Konstytucja RP z 2 kwietnia 1997 r. jest najważniejszym aktem prawnym regulującym obszar praw i wolności mniejszości narodowych. Zgodnie z treścią art. 35 Rzeczpospolita Polska zapewnia obywatelom polskim należacym do mniejszości narodowych i etnicznych wolność zachowania i rozwoju własnego języka, zachowania obyczajów i tradycji oraz rozwoju własnej kultury. Mniejszości narodowe i etniczne maja prawo do tworzenia wtasnych instytucji edukacyjnych, kulturalnych i instytucji stuzacych ochronie tożsamości religijnej oraz do uczestnictwa w rozstrzyganiu spraw dotyczacych ich tożsamości kulturowej ${ }^{11}$. Cytowany artykuł RP został rozwinięty w dwóch ustawach: Ustawie z dnia 6 stycznia 2005 r. o mniejszościach narodowych i etnicznych oraz o języku regionalnym oraz Ustawie o systemie oświaty z dnia 7 września 1991 roku ${ }^{12}$. Ustawy regulują kwestię edukacji mniejszości narodowych, której głównym celem jest dbanie o ciągłość poczucia tożsamości narodowej, etnicznej, językowej i religijnej, a także podkreślają wagę nauki języka i geografii obszaru kulturowego, z którym utożsamia się mniejszość narodowa oraz historii kultury mniejszości, do jakiej należy uczeń.

Do najważniejszych aktów prawodawstwa europejskiego, które dotyczą praw mniejszości narodowych należą: Konwencja ramowa Rady Europy o ochronie mniejszości narodowych i Europejska karta języków regionalnych lub mniejszościowych. Wśród pozostałych aktów prawnych, które normują organizację systemu edukacji dzieci z grup mniejszości narodowych znajdują się następujące dokumenty:

\footnotetext{
${ }^{11}$ Konstytucja Rzeczypospolitej Polskiej z dnia 2 kwietnia 1997..., op.cit., art. 35, [dostęp: 13.03.2016].

12 Ustawa o systemie oświaty systemie oświaty z dnia z dnia 7 września 1991 r. (Dz.U. 2004 Nr 256, poz. 2572; Nr 273, poz. 2703 i Nr 281, poz. 2781), http://isap. sejm.gov.pl/DetailsServlet?id=WDU19910950425, [dostęp: 13.04.2016].
} 
- $\quad$ Rozporzadzenie Ministra Edukacji Narodowej z dnia 14 listopada 2007 r. w sprawie warunków i sposobu wykonywania przez przedszkola, szkoły i placówki publiczne zadań umożliwiających podtrzymywanie poczucia tożsamości narodowej, etnicznej i językowej uczniów należacych do mniejszości narodowych i etnicznych oraz postugujących się językiem regionalnym (Dz.U. Nr 214, poz. 1579, z późn. zm.);

- $\quad$ Rozporzadzenie Ministra Edukacji Narodowej z dnia 30 kwietnia 2007 r. w sprawie warunków i sposobu oceniania, klasyfikowania i promowania uczniów i stuchaczy oraz przeprowadzania sprawdzianów i egzaminów w szkołach publicznych (Dz.U. Nr 83, poz. 562, z późn. zm.);

- $\quad$ Rozporzadzenie Ministra Edukacji Narodowej z dnia 23 grudnia 2008 r. w sprawie podstawy programowej wychowania przedszkolnego oraz kształcenia ogólnego w poszczególnych typach szkót (Dz.U. z 2009 r. Nr 4, poz. 17);

- $\quad$ Rozporzadzenie Ministra Edukacji Narodowej z dnia 12 lutego 2002 r. w sprawie ramowych planów nauczania $w$ szkołach publicznych (Dz.U. Nr 51, poz. 458, z późn. zm.);

- Rozporzadzenie Ministra Edukacji Narodowej z dnia 8 czerwca 2009 r. w sprawie dopuszczenia do użytku w szkole programów wychowania przedszkolnego i programów nauczania oraz dopuszczania do użytku szkolnych podręczników (Dz.U. z 2009 r. $\mathrm{Nr}$ 89, poz. 730);

- $\quad$ Rozporzadzenie Ministra Edukacji Narodowej z dnia 21 maja 2001 r. $w$ sprawie ramowych statutów publicznego przedszkola oraz publicznych szkót (Dz.U. z 2001 r. Nr 61, poz. 624, z późn. zm.);

- Rozporzadzenie Ministra Edukacji Narodowej z dnia 19 listopada 2009 r. w sprawie placówek doskonalenia nauczycieli (Dz.U. Nr 200, poz. 1537, z późn. zm.);

- Rozporzadzenie Ministra Edukacji Narodowej z dnia 12 marca 2009 r. w sprawie szczegółowych kwalifikacji wymaganych od 
nauczycieli oraz określenia szkót i wypadków, w których można zatrudnić nauczycieli niemajacych wyższego wykształcenia lub ukończonego zakładu kształcenia nauczycieli (Dz.U. z 2009 r. $\mathrm{Nr} 50$, poz. 400);

- $\quad$ Rozporzadzenie Ministra Edukacji Narodowej z dnia 16 grudnia 2010 r. w sprawie podziału części oświatowej subwencji ogólnej dla jednostek samorzadu terytorialnego w 2011 r. (Dz.U. Nr 249, poz. 1659).

Podstawy prawne organizacji nauki i nauczania w języku mniejszości ukraińskiej w Polsce w ramach polskiego

systemu oświaty zostały uregulowane w następujących artykułach:

- $\quad$ Art. 11 Traktatu między Rzeczpospolita Polska a Ukraina o dobrym sąsiedztwie, przyjaznych stosunkach $i$ wspótpracy, Warszawa dnia 18 maja 1992 r. (Dz.U. z 2000 r. Nr 125, poz. 29);

- $\quad$ Art. 12 i 13 Umowy między Rządem Rzeczpospolitej Polskiej a Rzadem Ukrainy o wspótpracy $w$ dziedzinie kultury, nauki i oświaty, Kijów dnia 20 maja 1997 r. (Dz.U. z 2000 r. Nr 3, poz. 573);

- $\quad$ Art. 1 i 6 Porozumienia o współpracy między Ministrem Edukacji Narodowej Rzeczpospolitej Polskiej a Ministrem Oświaty i Nauki Ukrainy, Gorów Iławiecki dnia 2 lipca 2001 r. (M.P. z dnia 5 lutego 2002 r. $)^{13}$.

\section{b) Rozmieszczenie szkół z językiem ukraińskim w Polsce}

Polski system edukacji odpowiada za nauczanie języka mniejszości narodowych na wszystkich szczeblach oświaty - od wychowania przedszkolnego aż do końca szkoły ponadgimnazjalnej i egzaminu dojrzałości. Według najnowszych danych opublikowanych przez Główny Urząd Statystyczny w roku szkolnym 2014/2015 w szkołach organizujacych nauczanie oraz prowadzacych dodatkowe zajęcia edukacyjne dla dzieci i młodzieży wywodzacych się z mniejszości

${ }^{13}$ Strategia rozwoju mniejszości ukraińskiej w Polsce, Warszawa 2011, s. 8-9. 
narodowych i etnicznych oraz posługujących się językiem regionalnym, kształciło się łacznie 61,0 tys. dzieci i młodzieży (49,7 tys. w 815 szkołach podstawowych, 9,3 tys. w 298 gimnazjach i 2,0 tys. w 56 szkołach ponadgimnazjalnych) ${ }^{14}$. Szkoły podstawowe oraz gimnazja z językiem ukraińskim stanowią 11,2\% wyżej wymienionej liczby szkół, uczyło się w nich odpowiednio 948 (78 szkół) i 465 uczniów (46 szkół), zaś na poziomie ponadgimnazjalnym funkcjonowało 13 szkół z 333 uczniami ${ }^{15}$.

Ze względu na rozproszenie mniejszości ukraińskiej na terenie Polski w konsekwencji jej przeszłości historycznej, szkoły z nauczaniem języka ukraińskiego jako języka mniejszości znajdują się w kilkunastu województwach. Według danych GUS-u 1746 uczniów w roku szkolnym 2014/2015 na różnych etapach edukacji uczęszczało na zajęcia z językiem mniejszości ukraińskiej w następujących województwach: dolnośląskim, lubelskim, lubuskim, małopolskim, mazowieckim, podkarpackim, podlaskim, pomorskim, warmińsko-mazurskim, wielkopolskim i zachodniopomorskim. Liczba uczniów nieznacznie zwiększyła się w okresie ostatnich 5 lat, w roku szkolnym 2009/2010 wynosiła 1725 uczniów $^{16}$.

\section{c) Organizacja zajęć dla mniejszości ukraińskiej w Polsce}

Zasady przeprowadzania lekcji w szkołach z językiem mniejszości reguluje Rozporządzenie Ministra Edukacji Narodowej z dnia 14 listopada 2007 r. w sprawie warunków i sposobu wykonywania przez przedszkola, szkoty i placówki publiczne zadań umożliwiajacych podtrzymywanie poczucia tożsamości narodowej, etnicznej i językowej

${ }^{14}$ Oświata $i$ wychowanie $w$ systemie szkolnym 2014/2015, http://stat.gov.pl/files/gfx/portalinformacyjny/pl/defaultaktualnosci/5488/1/9/1/ oswiata_i_wychowanie_w_roku_ szkolnym_2014-2015.pdf, [dostęp: 12.03.2016].

${ }^{15}$ Ibidem.

${ }^{16}$ Nijakowski L., Oświata mniejszości narodowych w Polsce, http://zielonewiadomosci.pl/tematy/mniejszosci/oswiata-mniejszosci-narodowych-w-polsce, [dostęp: 21.02.2016]. 
uczniów należących do mniejszości narodowych i etnicznych oraz postugujacych się językiem regionalnym (Dz.U. Nr 214, poz. 1579, z późn. zm.). Na poziomie ponadgimnazjalnym (liceum profilowane, uzupełniające liceum ogólnokształcące i technikum uzupełniające), obowiązują przepisy z Rozporządzenia Ministra Edukacji Narodowej i Sportu z dnia 12 lutego 2002 r. w sprawie ramowych planów nauczania w szkołach publicznych (Dz.U. Nr 15, poz. 142, z późn. zm.) ${ }^{17}$.

Zajęcia w szkołach podstawowych odbywają się w języku mniejszości, z wyłączeniem lekcji dotyczących kształcenia zintegrowanego języka polskiego oraz (w późniejszym etapie nauki) zajęć z języka polskiego i określonego obszaru z zakresu historii i społeczeństwa państwa polskiego. W pozostałych typach szkół wyróżnionymi zajęciami, nie objętymi programem nauczania języka mniejszości, jest język polski, część historii i część geografii dotyczące Polski. Nauka w języku mniejszości może być również zorganizowana w szkołach lub oddziałach dwujęzycznych, gdzie język mniejszości jest drugim językiem. Kolejnym typem szkoły lub oddziału przystosowanym do tego typu nauczania są szkoły, w których nauczanie języka mniejszości odbywa się jedynie w formie zajęć dodatkowych i zajęć z języka mniejszości. Pozostałe przedmioty wykładane są w języku polskim.

W zależności od potrzeb i możliwości nauczanie w języku mniejszości może odbywać się w klasach lub grupach międzyklasowych. Jest to uzależnione od liczby chętnych, zgłoszonych do udziału w lekcjach nauczania ukraińskiego. Na etapie przedszkolnym, szkoły podstawowej bądź gimnazjum grupa/oddział powinien liczyć co najmniej 7 dzieci, a na poziomie szkoły ponadgimnazjalnej liczba uczestników zajęć wzrasta do co najmniej 14 zainteresowanych osób ${ }^{18}$.

\footnotetext{
${ }^{17}$ Ibidem.

${ }^{18}$ Machul-Telus B., Majewska M., Edukacja mniejszości narodowych i etnicznych oraz społeczności postugującej się językiem regionalnym w Polsce 2010-2011, Warszawa 2012, s. 30-41.
} 
Język mniejszości został włączony do wykazu obowiązkowych zajęć szkolnych, zaś historia i kultura kraju mniejszości są zajęciami dodatkowymi: by w nich uczestniczyć uczeń powinien złożyć odpowiedni wniosek. Minimalna liczba godzin nauki języka mniejszości to: w klasach I-III szkoły podstawowej - 450 godzin, w klasach IV-VI i gimnazjum - po 380 godzin, w liceum ogólnokształcącym - 360 godzin. Wcześniej wspomniane w tym rozdziale akty prawne regulują również minimalną liczbę godzin nauki własnej historii i kultury, na każdym etapie edukacji (w klasach IV-VI szkoły podstawowej, gimnazjum, szkole zawodowej, liceum ogólnokształcącym) wynosi $30 \operatorname{godzin}^{19}$.

d) Podstawa programowa, podręczniki do nauki w języku mniejszości ukraińskiej

Podstawa programowa nauczania języka mniejszości w szkołach jest regulowana przez Rozporzadzenie Ministra Edukacji Narodowej z dnia 23 grudnia 2008 r. w sprawie podstawy programowej wychowania przedszkolnego oraz kształcenia ogólnego w poszczególnych typach szkót (Dz.U. z 2009 r. Nr 4, poz. 17). Jej część dotycząca nauczania języka mniejszości została opracowana przez zespół nauczycieli wybranych przez środowiska mniejszości narodowych i etnicznych.

Podstawa programowa obowiązująca na każdym poziomie kształcenia została opracowana, aby ustalić cele i treści nauczania, przedstawić plan wychowawczy szkoły i określić wyraźne wymagania egzaminacyjne i kryterium oceniania. Głównym celem autorów podręczników szkolnych jest dostosowanie swoich prac do obowiązującej podstawy programowej ${ }^{20}$.

Obecnie tworzenie programu szkolnego jest wyłącznie w kompetencji środowisk nauczycielskich. Zostało to uregulowane Rozporzadzeniem Ministra Edukacji Narodowej z dnia 8 czerwca 2009 r.

\footnotetext{
${ }^{19}$ Strategia rozwoju.., op.cit., s. 12-18.

${ }^{20}$ Ibidem.
} 
w sprawie dopuszczania do użytku w szkole programów wychowania przedszkolnego i programów nauczania oraz dopuszczania do użytku szkolnych podręczników (Dz.U. z 2009 r., Nr 89, poz. 730). Zgodnie $\mathrm{z}$ art. $22 \mathrm{a}$ ust. 8 Ustawy o systemie oświaty zmienił się proces wyboru programu nauczania w danej placówce. Według nowych rozporządzeń to dyrektor placówki po zaciągnięciu opinii rady pedagogicznej decyduje o wyborze programu nauczania i w konsekwencji o podręcznikach szkolnych. Poprzednio osobą kompetentną w sprawie wyboru treści nauczania w szkołach był minister do spraw oświaty i wychowania. Ministerstwo Edukacji Narodowej decyduje nadal o dopuszczeniu podręczników do użytku szkolnego, od lat nieodpłatnie zapewnia i przekazuje do bibliotek szkolnych podręczniki i książki pomocnicze, które umożliwiają naukę języka mniejszości narodowej, jej historii, kultury i geografii państwa, z którym utożsamia się uczeń21

Podręczniki wybierane przez dyrektorów szkół dla uczniów klas I-III szkoły podstawowej mogą pochodzić z wykazu podręczników dopuszczonych do użytku szkolnego, dedykowanych do nauczania w języku mniejszości, które zawierają podstawę programową opisaną w Rozporzadzeniu Ministra Edukacji Narodowej z dnia 23 grudnia 2008 r. w sprawie podstawy programowej wychowania przedszkolnego oraz kształcenia ogólnego w poszczególnych typach szkół (Dz.U. Nr 4, poz. 17) ${ }^{22}$. Wykaz podręczników do nauczania w języku ukraińskim jako języku mniejszości dla szkół podstawowych klas I-III, zgodny z wyżej wymienionym Rozporządzeniem, znajduje się na stronie internetowej Ministerstwa ${ }^{23}$.

\footnotetext{
${ }^{21}$ Pytania i odpowiedzi, https://men.gov.pl/zycie-szkoly/program-darmowy-podrecznik/dotacja-celowa-na-podreczniki/pytania-odpowied zi.html, [dostęp: 21.02.2016]. ${ }^{22}$ Ridna Mowa, Problemy oświaty, http:/www.interklasa.pl/portal/dokumenty/ ridna_mowa_pl/index.php?page=podstawa-programowa, [dostęp: 21.02.2016].

${ }^{23}$ Wykaz podręczników dopuszczonych do użytku szkolnego dla mniejszości narodowych $i$ etnicznych, http://men.gov.pl/podreczniki/wykaz_dopuszczone_lista2. php, [dostęp: 10.03.2016].
} 
Regulację prawną dotyczącą podstawy programowej funkcjonującą w klasach IV-VI, gimnazjach i szkołach ponadgimnazjalnych zapewniają artykuły Rozporzadzenia Ministra Edukacji Narodowej i Sportu z dnia 26 lutego 2002 r. w sprawie podstawy programowej wychowania przedszkolnego i ksztatcenia ogólnego w poszczególnych typach szkót (Dz.U. 2002 Nr 51, poz. 458, z późn. zm.) $)^{24}$. W wyniku działań MEN-u trwają konsultacje społeczne w sprawie zmiany podstawy programowej w zakresie wychowania przedszkolnego i edukacji wczesnoszkolnej25.

e) Egzamin maturalny z języka mniejszości ukraińskiej

\section{w Polsce}

Maturzyści ze szkół lub oddziałów z nauczaniem języków mniejszości są zobligowani do przystąpienia do egzaminu maturalnego z tego języka w części pisemnej i ustnej. Zgodnie z przepisami Rozporządzenia Ministra Edukacji Narodowej z dnia 30 kwietnia 2007 r. w sprawie warunków i sposobu oceniania, klasyfikowania i promowania uczniów i stuchaczy oraz przeprowadzania egzaminów i sprawdzianów w szkołach publicznych (Dz.U. 2007 Nr 83, poz. 562, z późn. zm.) absolwenci tych szkół mają możliwość wybrania wśród przedmiotów do zdawania przedmioty w języku polskim lub - z wyłączeniem przedmiotów: język polski oraz dotyczących treścią historii i geografii Polski - w języku danej mniejszości. Uczeń deklaruje język, w którym będzie zdawał przedmiot odpowiednio wcześniej ${ }^{26}$.

${ }^{24}$ Rozporzadzenie Ministra Edukacji Narodowej i Sportu z dnia 26 lutego 2002 r. $w$ sprawie podstawy programowej wychowania przedszkolnego $i$ ksztatcenia ogólnego w poszczególnych typach szkót (Dz.U. 2002 Nr 51, poz. 458, z późn. zm.), http://isap.sejm.gov.pl/DetailsServlet?id=WDU20020510458, [dostęp: 20.02.2016].

${ }_{25}$ Podstawa programowa wychowania przedszkolnego i ksztatcenia ogólnego rozpoczynamy konsultacje, https://men.gov.pl/ministerstwo/informacje/zalaczniknr-2-edukacja-wczesnoszkolna.html, [dostęp: 20.02.2016].

${ }^{26}$ Informacja na XL Posiedzenie Komisji Wspólnej Rządu i Mniejszości Narodowych i Etnicznych na 2 października 2013 r., http://mniejszosci.narodowe.mac.gov.pl/mne/ komisja-wspolna/aktualnosci/7259, Informacja-o-XL-posiedzeniu-Komisji-WspolnejRzadu-i-Mniejszosci-Narodowych-i-Et.html, [dostęp: 19.02.2016]. 
Zgodnie z danymi Centralnej Komisji Egzaminacyjnej w 2013 r. egzamin maturalny z języka ukraińskiego jako języka mniejszości napisało 90 osób, w 2014 r. - 72, zaś w 2015 r. - 70²7.

\section{f) Finansowanie działalności szkół z nauką języka mniejszości ukraińskiej}

Wydatki związane z funkcjonowaniem szkół podejmujących działania na rzecz pielęgnowania tożsamości kulturowej i językowej uczniów z grup mniejszości narodowych są ustawowo pokrywane przez samorząd terytorialny. Źródłem dochodu jednostek terytorialnych są wpływy z części oświatowej subwencji ogólnej. Wysokość otrzymanej kwoty dla każdej jednostki terytorialnej jest regulowana przepisami z Rozporzadzenia Ministra Edukacji Narodowej [ostatnie pochodzi z dnia 22 grudnia 2015 r.] w sprawie sposobu podziału części oświatowej subwencji ogólnej dla jednostek samorządu terytorialnego w 2016 r. (Dz.U. 2015, poz. 2294) ${ }^{28}$. W 2010 r. szkoły z nauczaniem języka ukraińskiego jako języka mniejszości, otrzymały z oświatowej subwencji ogólnej 12764210 złotych $^{29}$.

\section{Problematyka szkolnictwa mniejszości polskiej na Ukrainie}

a) Akty prawne regulujące politykę językową wobec mniejszości polskiej na Ukrainie

Podstawowym aktem prawnym na Ukrainie regulującym prawa mniejszości narodowych, w tym przestrzeganie prawa do nauczania w języku mniejszości, jest Konstytucja Ukrainy. Art. 10 umożliwia współistnienie na terenie Ukrainy również innych języków: $\mathrm{Na}$

${ }^{27}$ Oświata i wychowanie.., op.cit., [dostęp: 22.03.2016].

${ }^{28}$ Informacje o wysokości środków przeznaczonych dla poszczególnych samorzadów na oświate mniejszości narodowych i etnicznych oraz na nauczanie języka regionalnego $w$ ramach części oświatowej subwencji ogólnej w roku 2015, http:// mniejszosci.narodowe.mac.gov.pl/mne/oswiata/informacje-dotyczace-o/rok-szkolny-20142015/8869,Informacje-o-wysokosci-srodkow-przeznaczonych-dla-poszczegolnych-samorzadow-na-o.html, [dostęp: 19.02.2016].

${ }^{29}$ Oświata $i$ wychowanie.., op.cit., [dostęp: 22.03.2016]. 
Ukrainie gwarantuje się swobodny rozwój, używanie i ochronęjęzyka rosyjskiego oraz innych języków mniejszości narodowych Ukrainy. Państwo popiera naukęjęzyków obcych, umożliwiających porozumiewanie się między narodami. Możliwość stosowania różnych języków na Ukrainie gwarantuje konstytucja Ukrainy, a określa ustawa ${ }^{30}$. Kolejnym ważnym zapisem w Konstytucji Ukrainy, stanowiącym podstawę prawną dla nauczania w języku polskim jest art. 53 o treści: Obywatelom należacym do mniejszości narodowych gwarantuje się, zgodnie z ustawa, prawo do nauki w języku ojczystym lub nauki języka ojczystego w państwowych i komunalnych instytucjach nauczania albo $w$ ośrodkach kultury narodowej ${ }^{31}$. Następnym, bardzo istotnym dla mniejszości narodowych dokumentem jest Ustawa o mniejszościach narodowych na Ukrainie. Akt prawny, uchwalony przez Radę Najwyższą Ukrainy 25 czerwca 1992 r., składa się z 19 artykułów, zaś najważniejszym dla polskiej mniejszości artykułem, który prawnie umożliwia jej nauczanie w języku mniejszości, jest zapis w art. 6, zgodnie z którym państwo gwarantuje wszystkim mniejszościom narodowym prawa autonomii narodowo-kulturalnej: postugiwanie sie i nauczanie w języku ojczystym, czyli uczenie się języka ojczystego w szkołach państwowych albo w narodowych stowarzyszeniach kulturalnych, rozwój narodowych tradycji kulturalnych, używanie symboliki narodowej, obchodzenie świat narodowych, wyznawanie swojej religii, zaspokajanie potrzeb w zakresie literatury, sztuki, środków masowego przekazu, tworzenie narodowych instytucji kulturalnych oraz szkolnych i wszelka inną działalność, która nie przeczy obowiązujacemu prawodawstwu $u^{32}$.

\footnotetext{
${ }^{30}$ Konstytucja Ukrainy, rozdział I, art. 10, http://libr.sejm.gov.pl/tek01/txt/konst/ ukraina-r0.html, [dostęp: 05.03.2016].

${ }^{31}$ Ibidem.

32 Łodziński S., Ochrona praw osób należacych do mniejszości narodowych i etnicznych (Ukraina, Białoruś, Litwa, Łotwa), http://biurose.sejm.gov.pl/teksty_ pdf_98/i-598.pdf, [dostęp: 25.03.2016].
} 
Ze względu na mnogość języków mniejszości na Ukrainie funkcjonuje wciąż odrębny akt prawny (Ustawa Ukraińskiej Socjalistycznej Republiki Radzieckiej Ojęzykach w Ukraińskiej SRR z późniejszymi zmianami z dnia 22 października 1989 r.), która normuje zakres ochrony prawnej wobec języków i chroni je m.in. przed dyskryminacją. Art. 25 tej Ustawy pozwala na wprowadzenie zajęć z nauczania języka polskiego do ukraińskiego systemu oświaty, wskazując, że swobodny wybór języka nauczania jest niezbywalnym prawem obywateli oraz że państwo ukraińskie gwarantuje każdemu dziecku prawo do wychowania i pobierania nauki w języku narodowym. Efektem działania Ustawy są oddziały przedszkoli i szkół, w których edukacja prowadzona jest w języku ukraińskim oraz w językach innych narodowości. Nauczanie języków innych narodowości, w tym polskiego, w szkołach powszechnych reguluje art. $27 \mathrm{w}$ brzmieniu: W miejscach zwartego zamieszkania obywateli innych narodowości moga być otwierane szkoły powszechne, w których nauczanie i proces wychowawczy prowadzi się w ich języku albo w innym [...] moga być otwierane szkoły powszechne, w których nauczanie i proces wychowawczy prowadzi się w języku wspólnie wybranym przez rodziców uczniów $w^{33}$.

Regulacje dotyczące nauki w języku polskim znajdują się również w Umowie między Rządem Ukrainy a Rzadem Rzeczypospolitej Polskiej o wspótpracy w dziedzinie kultury, nauki i oświaty podpisanej 20 maja 1997 roku. Spisany w 26 artykułach dokument dotyczy przede wszystkim organizacji nauki języka na uczelniach wyższych, określając ramy współpracy i wzajemnej pomocy w tej kwestii między państwami. Wśród najważniejszych artykułów tej ustawy znajduje się art. 12, zgodnie z którym oba państwa stawiają sobie za cel tworzenie

${ }^{33}$ Ustawa Ukraińskiej Socjalistycznej Republiki Radzieckiej O językach w Ukraińskiej SRR (z późniejszymi zmianami) z dnia 22 października 1989 r.; Fragmenty, [w:] Wybór dokumentów prawnych..., s. 36-39, Закон СССР от 05.03.1991 N 1999-1. О внесении изменений и признании утратившими силу законодательных актов Союза ССР в связи с Законом СССР „О языках народов СССР”, http://www.zonazakona.ru/law/docs_ussr/435/, [dostęp: 25.03.2016]. 
warunków sprzyjających zachowaniu, rozwojowi $i$ wyrażaniu ich tozsamości narodowej, religijnej, kulturowej i jezzykowej bez jakiejkolwiek dyskryminacji i na warunkach petnej równości.

W artykule 13 Umowy strony ustaliły ramy organizacyjne swoich działań. Zajęcia z nauki języka mniejszości oraz z historii i kultury ojczystej mniejszości winny odbywać się w przedszkolach, szkołach podstawowych i średnich oraz zostać włączone do narodowych systemów edukacji. Ponadto oba państwa mają zadbać o wyższy poziom merytorycznej wiedzy dostarczanej przez nauczycieli tych przedmiotów poprzez szkolenia i właściwe przygotowanie kadr nauczycielskich ${ }^{34}$.

\section{b) Rozmieszczenie szkół z językiem polskim na Ukrainie}

Szacowana liczba osób uczących się języka polskiego według danych MOiN Ukrainy, Centrum Metodycznego Języka i Kultury Polskiej w Drohobyczu, a także placówek konsularnych na Ukrainie, wynosi ok. 25000 osób. Na Ukrainie istnieje łącznie prawie 300 punktów, w których odbywają się zajęcia w języku polskim. Mimo dużej powierzchni państwa ukraińskiego oraz rozproszenia po kraju członków mniejszości polskiej, najwięcej placówek z językiem polskim znajduje się w obwodach: żytomierskim (Wołyń Wschodni), lwowskim i tarnopolskim (Galicja), chmielnickim i winnickim (Podole) oraz w obwodzie czerniowieckim (Bukowina) ${ }^{35}$.

Zgodnie $\mathrm{z}$ danymi przedstawionymi przez portal Zjednoczenia Nauczycieli Polskich na Ukrainie „Edukator”, system oświaty polskojęzycznej na terenie Ukrainy stanowią następujące placówki:

\footnotetext{
${ }^{34}$ Umowa między Rządem Rzeczypospolitej Polskiej a Rządem Ukrainy o wspótpracy $w$ dziedzinie kultury, nauki $i$ oświaty, sporzadzona $w$ Kijowie dnia 20 maja 1997 r., (Dz.U. z 2000 r., nr 3, poz. 29), http://isip.sejm.gov.pl/DetailsServlet?id=WDU20000030029, [dostęp: 12.03.2016].

${ }^{35}$ Polskie Szkoty na Ukrainie i Białorusi: Rozdział I Polityka Polski i Ukrainy wobec polskiej mniejszości narodowej na Ukrainie, http://polskieszkoly.org/artykuly/5/ ROZDZIAL-I-POLITYKA-POLSKI-I-UKRAINY-WOBEC-POLSKIEJMNIEJSZOSCI-NARODOWEJ-NA-UKRAINIE.html, [dostęp: 29.03.2016].
} 
- $\quad$ szkoły z polskim jako językiem wykładowym (6 placówek): szkoła ogólnokształcąca z polskim językiem nauczania w Gródku Podolskim, Szkoła Średnia Nr 24 im. M. Konopnickiej we Lwowie, Szkoła Średnia Nr 10 we Lwowie, szkoła nauczania początkowego z języka polskiego w Łanowicach, Szkoła Średnia $\mathrm{Nr} 3$ z polskim językiem nauczania w Mościskach, szkoła podstawowa z polskim językiem nauczania w Strzelczyskach. W roku szkolnym 2014/2015 uczyło się w nich łącznie ok. 3000 uczniów;

- $\quad$ szkoły dwujęzyczne ze specjalnie wydzielonymi klasami ,polskimi”, w których zajęcia są prowadzone w języku polskim (2 placówki): Iwano-Frankiwsk i Szpetówka;

- $\quad$ szkoły z pogłębioną nauką języka polskiego dla mniejszości (6 szkół: 5 średnich i 1 podstawowa). W większości tych szkół na każdym poziomie nauczania funkcjonuje tylko jedna taka klasa;

- $\quad$ szkoły średnie, tzw. szkoły ukraińskie, w których język polski jest przedmiotem obowiązującym jako język obcy do wyboru (15 szkół) oraz szkoły średnie, gdzie języki polski występuje w formie przedmiotu fakultatywnego (147 placówek);

- $\quad$ przedszkole z polskim językiem nauczania w Łanowicach (jedyne na Ukrainie), grupy przedszkolne we Lwowie, Kamieńcu Podolskim i Strzelczyskach ${ }^{36}$.

Kolejnym ważnym elementem systemu oświaty polskiej na Ukrainie są szkoły sobotnio-niedzielne, w których zajęcia prowadzone są zarówno dla dzieci, młodzieży, jak i dla dorosłych. Szkoły tego typu najczęściej działają przy szkołach publicznych, polskich stowarzyszeniach lub parafiach rzymskokatolickich. Liczba uczniów w każdej szkole jest bardzo zróżnicowana, od 14 słuchaczy po 528. Zdecydowanie przeważają jednak mniej liczebne placówki, uczące poniżej 100 osób. Fundacja Wolność i Demokracja w swoim raporcie na lata 2013-2014 podaje, że na Ukrainie polskie szkoły sobotnio-

${ }^{36}$ Lista szkót, http://polacy.info.pl/pl/lista-szkol/, [dostęp: 29.03.2016]. 
-niedzielne prowadziły zajęcia z języka polskiego dla 3675 uczniów, zdecydowana większość słuchaczy to Polacy i osoby polskiego pochodzenia. Program nauczania, na podstawie którego prowadzone są zajęcia w szkołach sobotnio-niedzielnych nie jest zatwierdzony przez Ministerstwo Oświaty i Nauki Ukrainy przede wszystkim z powodu braku odpowiednich ministerialnych podręczników do nauki języka polskiego oraz nieposiadania przez szkoły statusu szkół publicznych, co uniemożliwia im realizację zaleceń ministerstwa. Zdecydowana większość szkół sobotnio-niedzielnych jest finansowana ze źródeł prywatnych - dobrowolnych składek rodziców, wsparcia pieniężnego od konsulatu, stowarzyszeń i fundacji. Zgodnie z danymi Fundacji Wolność i Demokracja takich placówek w podanych wyżej latach na Ukrainie (zarejestrowanych jako szkoły sobotnio-niedzielne w ukraińskim systemie oświaty i niezarejestrowanych) było $137^{37}$.

Prężnie działające na Ukrainie polskie organizacje i stowarzyszenia również prowadzą zajęcia z nauczania języka polskiego. Zgodnie z powyższym raportem Poloniana Ukrainie utworzyła 139 ośrodków, w których prowadziła zajęcia dla około 2260 osób ${ }^{38}$.

\section{c) Organizacja zajęć mniejszości polskiej na Ukrainie}

Formę, zakres treści i liczbę godzin nauczania języka polskiego w szkolnictwie ukraińskim szczegółowo określa Rozporzadzenie nr 409 Ministerstwa Oświaty i Nauki Młodzieży i Sportu Ukrainy z 3 kwietnia 2012 roku. Kwalifikuje ono nauczanie języka polskiego w ukraińskich placówkach edukacyjnych jako naukę języka obcego i mowy mniejszości narodowej. Realizując cele Rozporządzenia, na Ukrainie funkcjonują dwa różne rodzaje programów do nauczania języka polskiego, dla uczniów klas I-IX oraz klas V-IX. Minister-

\footnotetext{
${ }^{37}$ Placówki oświatowe na Ukrainie Informator, Warszawa 2015, s. 12.

${ }^{38}$ Ibidem.
} 
stwo ustala roczny plan nauczania języka, w którym liczba godzin na poszczególnym szczeblu edukacji zależy od typu szkoły ${ }^{39}$.

Zgodnie z załącznikiem nr 2 Rozporzadzenia liczba godzin nauczania języka mniejszości narodowej w kolejnych klasach wygląda następująco: klasa V - 3 godz., klasa VI - 3,5 godz., klasa VII - 2,5 godz., klasy VIII i IX - 2 godz. tygodniowo. Dla porównania liczba godzin nauczania drugiego języka obcego wynosi 2 godz. w klasach od V do IX. Załącznik nr 3 ustala, że w szkołach „specjalizowanych z wykładowym językiem ukraińskim i pogłębionym nauczaniem języków obcych" w klasach V-IX uczniowie będą tygodniowo uczęszczać na 5 godz. zajęć z pierwszego języka obcego i na 2 godz. kolejnego języka obcego.

Z kolei załącznik nr 4 Rozporządzenia przewiduje dla szkół „specjalizowanych z nauczaniem języków mniejszości narodowych i pogłębionym nauczaniem języków obcych" 2 godz. zajęć na tydzień języka mniejszości narodowej i taką samą liczbę godzin z drugiego języka obcego w klasach $\mathrm{V}-\mathrm{IX}^{40}$.

Odrębne przepisy normują nauczanie w szkołach z wykładowym językiem ukraińskim. W takich placówkach edukacyjnych nauczanie języka mniejszości jest organizowanie na wniosek dzieci i rodziców. Zgodnie z Ustawa MOiN (Міністерство освіти і науки України) Ukrainy z 23.02.2004 nr 132 ze zmianami wniesionymi Ustawa MOiN Ukrainy z 05.02.2009 nr 66 nauczanie języków mniejszości prowadzone jest w dwóch wariantach. Pierwszy wariant przewiduje przyznanie nauczaniu języka mniejszości rangi przedmiotu obowiązkowego w klasach I-XI, w wymiarze 2 godz. na tydzień. Drugi

\footnotetext{
${ }^{39}$ Januszkiewicz B., Normy prawne funkcjonowania języka polskiego na Ukrainie, „Zeszyty Naukowe Uniwersytetu Rzeszowskiego Seria Filologiczna”, Zeszyt 86/2014: Dydaktyka 9.

${ }^{40}$ Rozporzadzenienr 664 z 29 maja 2014 r. http://mon.gov.ua/content/\%D0\%9E\%D1 \%81\%D0\%B2\%D1\%96\%D1\%82\%D0\%B0/nmon-664-29052014-(3).pdf, [dostęp: 03.03.2016].
} 
wariant zakłada nauczanie języka mniejszości w formie przedmiotu dodatkowego uzupełniającego dla klas $\mathrm{I}-\mathrm{V}^{41}$.

Ustawa umożliwia prowadzenie zajęć z nauczania języka mniejszości w trzech różnych postaciach - jako przedmiotu, specjalnego kursu lub fakultetu. Liczba godzin nauki oraz plan nauczania ustala administracja placówki oświatowej, biorąc pod uwagę sugestie zainteresowanych, czyli uczniów i ich rodziców.

Ostatnią formą nauczania języka mniejszości, w tym języka polskiego, są zajęcia w formie dodatkowego przedmiotu. Uczniowie mogę na nie uczęszczać, korzystając z puli godzin dodatkowych, tzw. godzin wariantywnych w klasach I-IV i dalej uczyć się w klasach $\mathrm{V}-\mathrm{IX}$ na zajęciach fakultatywnych ${ }^{42}$.

\section{d) Podstawa programowa, podręczniki do nauki mniejszości polskiej na Ukrainie}

Zajęcia z nauczania języka polskiego są przygotowywane według programów zatwierdzonych przez MOiN Ukrainy. Dodatkowo nauczyciele mogą tworzyć programy autorskie, które wymagają oficjalnej akceptacji ze strony miejscowego kuratorium oświaty. Ponadto istnieje polska podstawa programowa, napisana w latach 2010-2012 na polecenie polskiego MEN-u, na której również bazuje program nauczania. Szkoły sobotnio-niedzielne najczęściej prowadzą zajęcia z nauczania języka polskiego zgodne z indywidualnym, niezatwierdzonym przez MOiN Ukrainy programem, z wykorzystaniem dowolnych podręczników. W szkołach publicznych, działających pod patronatem ukraińskiego systemu oświaty, do nauki dopuszczane są tylko podręczniki, które zyskały aprobatę MOiN-u Ukrainy ${ }^{43}$.

Podręczniki dostarczają trzy wydawnictwa: „Świt”, „Geneza” oraz „Bukrek”. Ich druk zleca MOiN Ukrainy, a następnie gotowe książki są nieodpłatnie udostępniane w szkołach. Ponadto nauczyciele

\footnotetext{
${ }^{41}$ Januszkiewicz B., Normy prawne.., op.cit., s. 8.

${ }^{42}$ Fundacja Wolność i Demokracja, Placówki..., op.cit., s. 15-17.

${ }^{43}$ Januszkiewicz B., Normy prawne.., op.cit., s. 7.
} 
języka polskiego na Ukrainie wśród najczęściej używanych książek do nauki polskiego wymieniają podręczniki polskich wydawnictw „Universitas” i „Prolog”: „Hurra po polsku 1, 2, 3”, „Czas na czasownik”, ,Z polskim na ty B1”, „, Gramatyka? Dlaczego nie!”, „Przygoda z gramatyką”, „Liczebnik też się liczy” czy wreszcie „Nie ma róży bez kolców"44.

\section{e) Egzamin maturalny z języka polskiego jako języka mniej- szości na Ukrainie}

W wyniku starań Związku Polaków na Ukrainie, polskiego MEN oraz Ambasady RP w Kijowie Ministerstwo Oświaty i Nauki Ukrainy zmieniło własne rozporządzenie z września ubiegłego roku, usuwające język polski (mniejszości narodowej) z listy przedmiotów maturalnych.

Zgodnie z nieaktualną dziś nowelizacją Rozporządzenia Ministerstwa Oświaty i Nauki Ukrainy nr 940 z dnia 16 września 2015 r. język ojczysty, czyli również język polski, nie został wpisany na listę przedmiotów maturalnych w roku szkolnym 2015/2016. MOiN Ukrainy zatwierdziło listę, zgodnie z którą możliwość przystąpienia do egzaminu maturalnego z polskiego w roku szkolnym 2015/2016 mieli tylko dziewięcioklasiści (II stopień nauczania, odpowiednik polskiego egzaminu gimnazjalnego) po wydaniu pozytywnej decyzji rady pedagogicznej placówki szkolnej. W dniu 31 marca 2016 r. odbyło się spotkanie resortu Ministerstwa Oświaty i Nauki Ukrainy, na którym na wniosek Związku Polaków Ukrainy dyskutowano o możliwości podejścia do egzaminu maturalnego z języka ojczystego również przez uczniów, którzy ukończyli III stopień nauczania (jedenastoklasiści).

Do matury z polskiego przystąpić mogą tylko uczniowie szkół z polskim językiem nauczania oraz placówek, gdzie język polski jest wykładany jako oddzielny przedmiot, a nie w trybie fakultatyw-

\footnotetext{
${ }^{44}$ Wątróbski L., O nauce języka polskiego na Ukrainie, http://polscott24.com/polskie-szkolnictwo-na-ukrainie/, [dostęp: 03.03.2016].
} 
nym. Język polski (mniejszości narodowej) to obecnie jeden z dwóch przedmiotów do wyboru. Dodatkowo uczniowie obowiązkowo zdają język ukraiński, język obcy (angielski, niemiecki, francuski) oraz matematykę/historię Ukrainy ${ }^{45}$.

W 2015 r. na Ukrainie polskiego jako języka mniejszości uczyło się 26,3 tys. uczniów ${ }^{46}$.

\section{f) Finansowanie działalności szkół z nauką języka mniej- szości polskiej}

Ukraińskie szkolnictwo publiczne, w ramach którego prowadzone są zajęcia z nauczania języka polskiego dla mniejszości polskiej (szkoły z polskim językiem wykładowym, szkoły z klasami ,polskimi”, szkoły z pogłębioną nauką polskiego oraz placówki, w których język polski funkcjonuje jako przedmiot obowiązkowy lub fakultatywny), zgodnie z Ustawa o oświacie z 1991 r. z późniejszymi zmianami są finansowane ze środków publicznych i podlegają władzom samorządowym.

Szkoły społeczne, czyli szkoły sobotnio-niedzielne działające przy polskich organizacjach lub parafiach rzymskokatolickich, jak już była mowa, są finansowane na innych warunkach niż szkoły publiczne. Niewielki odsetek z nich korzysta wyłącznie lub częściowo ze wsparcia publicznego, tj. pieniędzy ze źródeł miejskich. Wydatki na ich działalność są pokrywane przede wszystkim przez rodziców uczniów oraz z innych źródeł (fundacje, stowarzyszenia, instytucje rządowe i samorządowe z Polski itd.).

Punkty nauczania języka polskiego, które prowadzą działalność przy organizacjach polskich, parafiach rzymskokatolickch i szkołach

\footnotetext{
${ }^{45}$ Matura z polskiego wróciła na listę przedmiotów maturalnych na Ukrainie!, http://z-p-u.org/index.php/2016/05/30/matura-z-polskiego-wrocila-na-liste-przedmiotow-maturalnych-na-ukrainie/, [dostęp: 10.06.2016].

46 Ministerstwo Oświaty Ukrainy odpisało $w$ sprawie matury z polskiego, http://zp-u.org/index.php/2016/03/30/ministerstwo-oswiaty-ukrainy-odpisalo-w-sprawie-matury-z-polskiego/, [dostęp: 7.04.2016].
} 
ukraińskich wymieniają wśród źródeł finansowania przede wszystkim środki własne (m.in. składki członkowskie). Ponadto wsparcie pochodzi od rodziców uczniów, władz lokalnych i polskich źródeł finansowania (konsulat, instytucje rządowe i fundacji) ${ }^{47}$.

\section{Wyzwania edukacji mniejszości ukraińskiej w Polsce i pol- skiej na Ukrainie}

Najważniejsze wyzwania edukacji mniejszości ukraińskiej w Polsce zostały omówione podczas spotkania w Ministerstwie Spraw Wewnętrznych i Administracji w dniu 18 marca 2016 roku. Celem prowadzonych rozmów była ocena stanu realizacji Strategii rozwoju oświaty mniejszości ukraińskiej w Polsce, zatwierdzonej w 2011 r. przez Ministra Spraw Wewnętrznych i Administracji oraz Ministra Edukacji Narodowej. W spotkaniu wypowiadali się m.in.: Wicemarszałek Województwa Warmińsko-Mazurskiego, przedstawiciele ministerstw Spraw Wewnętrznych i Administracji oraz Edukacji Narodowej, organizacji mniejszości ukraińskiej i dyrektorzy oraz nauczyciele szkół z ukraińskim językiem nauczania.

Wśród najważniejszych problemów edukacji mniejszości ukraińskiej w Polsce uczestnicy spotkania wymienili niekompletną listę podręczników do nauczania, szczególnie dla klas I-III gimnazjum, których celem jest wspieranie poczucia tożsamości narodowej wśród uczniów wywodzących się z mniejszości ukraińskiej. Wskazano również na brak podręczników do nauczania historii i geografii Ukrainy, występujący na każdym stopniu edukacji, wynikający przede wszystkim z braku autorów gotowych podjąć się ich realizacji ${ }^{48}$. Mimo wprowadzenia Ustawy o zmianie Ustawy o systemie oświaty oraz niektórych innych ustaw z dnia 30 maja 2014 r. (Dz.U. 2014, poz.

\footnotetext{
${ }^{47}$ Placówki..., op.cit., s. 13-19.

${ }^{48}$ MonitorowanieStrategiirozwojuświatymniejszościukraińskiejwPolsce, http://mniejszosci.narodowe.mac.gov.pl/mne/oswiata/strategie-rozwoju-oswi/ukrainska/9841,Monitorowanie-Strategii-rozwoju-swiaty-mniejszosci-ukrainskiej-w-Polsce.html, [dostęp: 17.04.2016].
} 
811), która zakłada, że uczniowie szkół podstawowych i gimnazjów mają prawo do bezpłatnego dostępu do podręczników, materiałów edukacyjnych lub materiałów ćwiczeniowych, przeznaczonych do obowiązkowych zajęć edukacyjnych z zakresu kształcenia ogólnego, określonych w ramowych planach nauczania ${ }^{49}$, nauczyciele mniejszości ukraińskiej sygnalizują niewystarczającą liczbę podręczników do nauki w języku mniejszości zaakceptowanych przez MEN przede wszystkim dla uczniów uczęszczających na zajęcia na poziomie edukacji ponadpodstawowej (MEN jest jednostką odpowiedzialną za dostarczanie nieodpłatnych egzemplarzy do bibliotek szkolnych).

Podczas spotkania poruszono kwestię wielokrotnie podnoszoną podczas posiedzeń m.in. sejmowej Komisji Mniejszości Narodowych i Etnicznych oraz Komisji Wspólnej Rządu i Mniejszości Narodowych i Etnicznych - braku nauczycieli, konsultantów lub doradców metodycznych dla nauczycieli uczących w języku mniejszości. Mniejszość ukraińska ze względu na duże rozproszenie zgłaszała potrzebę wsparcia metodycznego w dziesięciu województwach (lubuskie, dolnośląskie, małopolskie, mazowieckie, podkarpackie, pomorskie, podlaskie, warmińsko-mazurskie, wielkopolskie, zachodniopomorskie). $\mathrm{W}$ konsekwencji zaledwie w czterech $\mathrm{z}$ nich zatrudniono doradców metodycznych języka ukraińskiego. Nie powstał również Centralny Ośrodek Wspierania Metodycznego Nauczycieli Języka Ukraińskiego, którego założenie wymieniono w Strategii rozwoju... z 2011 roku ${ }^{50}$.

Istotnym problemem dla edukacji mniejszości ukraińskiej w Polsce jest również konsekwentnie zmniejszająca się liczba uczniów szkół z ukraińskim językiem nauczania. Dla przykładu: w 2006/2007 było 777 uczniów, zaś już w 2009/2010 r. - 678. Oznacza to 39\% ubytek uczniów w trakcie dziesięciu lat (od roku szkolnego 1999/2000

\footnotetext{
${ }^{49}$ Ustawa o systemie oświaty z dnia 7 września 1991 r. (Dz.U. $2004 \mathrm{Nr}$ 256, poz. 2572; $N r$ 273, poz. 2703 i Nr 281, poz. 2781), http://isap.sejm.gov.pl/DetailsServlet?id=WDU20140000811, [dostęp: 13.04.2016].

${ }^{50}$ Monitorowanie Strategii..., op.cit., [dostęp: 13.04.2016].
} 
do 2009/2010). Powyższy problem występuje również w punktach nauczania języka ${ }^{51}$.

Kolejną kwestią pogarszającą ocenę edukacji mniejszości ukraińskiej w Polsce jest niski poziom nauki w punktach nauczania języka ukraińskiego, które stanowią najpopularniejszy ośrodek nauczania języka mniejszości. Związek Ukraińców w Polsce wśród wad punktów nauczania wymienia zajęcia dla dzieci z różnych grup wiekowych, znających język ukraiński w różnym stopniu zaawansowania, odbywające się w godzinach wieczornych. Ponadto zwraca uwagę na brak wsparcia ze strony dyrektorów i wsparcia metodycznego. Związek niepokoi również brak motywacji rodziców, którzy niejednokrotnie niewystarczająco angażują się w proces nauczania języka mniejszości przez ich dzieci.

Członkowie mniejszości ukraińskiej zwracają również uwagę na realną potrzebę utworzenia zespołów profesjonalnie przygotowanych do tworzenia programów nauczania i podręczników szkolnych. Ponadto mniejszość postuluje potrzebę finansowania szkoleń nauczycieli języka ukraińskiego ${ }^{52}$.

Strony ustaliły, że kilka kwestii zostanie ponownie omówionych po wprowadzeniu zmian, które są obecnie konsultowane w systemie oświaty. Jedną z nich było zwrócenie się przez Związek Ukraińców w Polsce oraz polski MEN do kilku uniwersytetów, m.in. do Warszawskiego, Jagiellońskiego i Łódzkiego z pytaniem o możliwości przygotowania przez ich wyspecjalizowaną kadrę podręczników do nauki języka ukraińskiego dla mniejszości. Byłaby to odpowiedź na problem braku podręczników do nauczania w języku mniejszości. Na dzień 17 kwietnia 2016 r. uczelnie nie przedstawiły oficjalnego stanowiska wobec propozycji współpracy.

\footnotetext{
${ }^{51}$ Łabowicz L., Ojczyste słowo to - рідна мова! Nauczanie języka ukraińskiego w Polsce po 1947 r., http://nadbuhom.pl/art_2692.html, [dostęp: 17.04.2016].

52 Łabowicz L., Ojczyste słowo to - рідна мова! Nauczanie języka ukraińskiego w Polsce po 1947 r., http://nadbuhom.pl/art_2692.html, [dostęp: 17.04.2016].
} 
W celu poprawy stanu edukacji mniejszości ukraińskiej w Polsce przewidziane są kolejne spotkania w Ministerstwie Spraw Wewnętrznych i Administracji, podczas których ponownie będą omawiane rezultaty wdrażania Strategii rozwoju oświaty mniejszości ukraińskiej $w$ Polsce $^{53}$.

Z nieco innymi problemami zmaga się mniejszość polska na Ukrainie. Wśród swoich największych potrzeb w dziedzinie edukacji wymienia ona konieczność standaryzowania programów nauczania (z języka i literatury polskiej, z historii i geografii Polski, z wiedzy o kulturze polskiej), doprowadzenia do ujednolicenia poziomu i zakresu wiedzy uczniów oraz wprowadzenia wspólnych metod oceniania ${ }^{54}$.

Nauczyciele polskiego jako języka mniejszości sygnalizują również zbyt małą liczbę podręczników do języka polskiego oraz podręczników z innych przedmiotów w języku polskim. Uczniowie mniejszości polskiej w szkołach publicznych, należących do ukraińskiego systemu oświaty, mogą korzystać wyłącznie z podręczników, które uzyskały akceptację MOiN Ukrainy. Książki są dostępne w szkołach nieodpłatnie, niestety w liczbie niewystarczającej, by trafiły do każdego ucznia ${ }^{55}$. Dużym problemem oświaty polskiej na Ukrainie są ceny podręczników, które w zasadzie należy zakupić samodzielnie, a które są wielokrotnie droższe od podręczników ukraińskich (dla przykładu: podręcznik do literatury ukraińskiej kosztuje 24 hrywny, a do literatury polskiej - 600 hrywien). Ze względu na stosunkowo mały nakład wielu uczniów nie ma do nich dostępu. Ponadto podręczniki tworzone w Polsce, mimo niższej ceny mogą być wykorzy-

\footnotetext{
${ }^{53}$ Monitorowanie Strategii..., op.cit., [dostęp: 13.04.2016].

${ }^{54}$ Zarys szkolnictwa polskiego na Ukrainie, http://polacy.info.pl/pl/zarys-szkolnictwa-polskiego-na-ukrainie/, [dostęp: 17.04.2016].

${ }^{55}$ Sierakowa J., Stan obecny i perspektywy szkolnictwa polskiego na Ukrainie, [w:] Język polski w ukraińskiej edukacji - perspektywy $w$ aspekcie integracji europejskiej, Warszawa 2014, s. 190-198.
} 
stywane przez nauczycieli jedynie w postaci pomocy dydaktycznej, ze względu na dużą różnicę programową w obu krajach ${ }^{56}$.

Kolejnym problemem szkolnictwa polskiego na Ukrainie jest brak spójnego systemu monitoringu działań oświaty mniejszości polskiej, który powinien być prowadzony przez instytucje ukraińskie razem z polskimi. Przykładem braku nadzoru jest nieporządkowanie i rozproszenie danych na temat liczby placówek nauczania języka polskiego, liczby uczniów, nauczycieli itd. Informacje są udostępnione do publicznego wglądu na stronach MOiN Ukrainy, stronach internetowych polskich konsulatów itd., lecz brakuje stałych aktualizacji danych, a ich przegląd utrudnia brak jednego źródła ze wszystkimi danymi ${ }^{57}$.

Kluczową kwestią do poprawy w celu podniesienia jakości edukacji polskiej na Ukrainie jest konieczność zadbania o kadrę nauczycielską, a zatem konieczność podwyższenia pensji polskim nauczycielom. Fundacja Wolność i Demokracja zwraca uwagę na nieatrakcyjność oferty pracy jako wykładowcy języka polskiego na Ukrainie i konkurencyjność (szczególnie finansową) ofert np. z konsulatu RP. Ponadto nauczyciele, szczególnie ze szkół sobotnio-niedzielnych, informują o złych warunkach lokalowych, które utrudniają prowadzenie zajęć w niektórych placówkach ${ }^{58}$.

Obecnie trwają prace nad stworzeniem strategii rozwoju oświaty polskiej na Ukrainie. Ministerstwo Oświaty i Nauki Ukrainy we współpracy z Fundacją Wolność i Demokracja planuje w tym roku wydać dokument, który będzie zawierał analizę stanu polskiego szkol-

\footnotetext{
${ }^{56}$ Polskie szkoty na Ukrainie: brak pieniędzy na podręczniki i pensje nauczycieli, http://www.oswiata.abc.com.pl/czytaj/-/artykul/polskie-szkoly-na-ukrainie-brak-pieniedzy-na-podreczniki-i-pensje-nauczycieli, [dostęp: 17.04.2016].

${ }^{57}$ Sierakowa J., Stan obecny i perspektywy..., op.cit., s. 190-198.

${ }^{58}$ PetnyzapisprzebieguposiedzeniaKomisjiEdukacji, NaukiiMłodzieży(nr113)Komisji Łączności z Polakamiza Granica (nr 49) z dnia 9 października 2013 r., http://orka.sejm. gov.pl/zapisy7.nsf/0/301BDB7F8B88558DC1257C080047B4C2/\%24File/0244007. pdf, [dostęp: 17.04.2016].
} 
nictwa na Ukrainie oraz wskaże działania, których realizacji powinna podjąć się polska oświata, by podtrzymać poczucie tożsamości narodowej wśród uczniów mniejszości polskiej. Zdaniem Fundacji strategia wskaże kierunki rozwoju szkolnictwa polskiej mniejszości oraz da podstawy prawne działaniom w celu rozwiązania narosłych problemów $^{59}$.

Temat szkolnictwa mniejszości ukraińskiej w Polsce i mniejszości polskiej na Ukrainie nie został wyczerpany i zamknięty. Znana jest już data kolejnego spotkania podmiotów zainteresowanych monitorowaniem wdrażania Strategii rozwoju oświaty mniejszości ukraińskiej w Polsce oraz podano publicznie informację o planowanej w tym roku dacie wydania strategii rozwoju oświaty polskiej na Ukrainie. Choć problemów w zakresie szkolnictwa mniejszościowego jest wiele w obu krajach, dzięki podjętemu dialogowi mają one szanse na pozytywne rozwiązanie.

\section{Bibliografia}

1. Biblioteka sejmowa, Konstytucja Ukrainy, rozdział I, art. 10, http://libr.sejm. gov.pl/tek01/txt/konst/ukraina-r0.html.

2. Fundacja Wolność i Demokracja, Placówki oświatowe na Ukrainie Informator, Warszawa 2015.

3. Fundacja Wolność i Demokracja, Powstanie strategia oświatowa dla szkolnictwa polskiego na Ukrainie, http://wid.org.pl/powstanie-strategia-oswiatowa-dla-szkolnictwa-polskiego-na-ukranie.

4. Główny Urząd Statystyczny, http://stat.gov.pl.

5. Internetowy system aktów prawnych, http://isap.sejm.gov.pl.

6. Januszkiewicz B., Normy prawne funkcjonowania języka polskiego na Ukrainie, „Zeszyty Naukowe Uniwersytetu Rzeszowskiego Seria Filologiczna”, Zeszyt 86/2014, Dydaktyka 9.

7. Kałakura J., Polacy na Ukrainie po rozpadzie ZSRS, http://kresy. wm.pl/226663,Polacy-na-Ukrainie-po-rozpadzie-ZSRS.html.

59 Powstanie strategia oświatowa dla szkolnictwa polskiego na Ukrainie, http:// wid.org.pl/powstanie-strategia-oswiatowa-dla-szkolnictwa-polskiego-na-ukranie/, [dostęp: 17.04.2016]. 
8. Łabowicz L., Ojczyste słowo to-pidна мова! Nauczanie języka ukraińskiego w Polsce po 1947 r., http://nadbuhom.pl/art_2692.html.

9. Łodziński S., Ochrona praw osób należacych do mniejszości narodowych i etnicznych (Ukraina, Białoruś, Litwa, Łotwa), http://biurose.sejm.gov.pl/ teksty_pdf_98/i-598.pdf.

10. Machul-Telus B., Majewska M., Edukacja mniejszości narodowych i etnicznych oraz społeczności postugującej się językiem regionalnym w Polsce 2010-2011., Warszawa 2012.

11. Ministerstwo Edukacji Narodowej i Ministerstwo Spraw Wewnętrznych i Administracji, Strategia rozwoju mniejszości ukraińskiej w Polsce, Warszawa 2011, s. 8-9.

12. Ministerstwo Edukacji Narodowej, https://men.gov.pl.

13. Ministerstwo Oświaty i Nauki Ukrainy, Rozporządzenie nr 664 z 29 maja 2014 r., http://mon.gov.ua/content/\%D0\%9E\%D1\%81\%D0\%B2\%D1\%96\% D1\%82\%D0\%B0/nmon-664-29052014-(3).pdf.

14. Ministerstwo Spraw Wewnętrznych i Administracji, Departament Wyznań Religijnych oraz Mniejszości Narodowych i Etnicznych, Informacje o wysokości środków przeznaczonych dla poszczególnych samorząów na oświate mniejszości narodowych i etnicznych oraz na nauczanie języka regionalnego w ramach części oświatowej subwencji ogólnej w roku 2015, http://mniejszosci.narodowe.mac.gov.pl/mne/oswiata/informacje-dotyczace-o/rok-szkolny20142015/8869,Informacje-o-wysokosci-srodkow-przeznaczonych-dla-poszczegolnych-samorzadow-na-o.html.

15. Mniejszości narodowe i etniczne, Monitorowanie Strategii rozwoju oświaty mniejszości ukraińskiej w Polsce, http://mniejszosci.narodowe.mac.gov.pl/ mne/oswiata/strategie-rozwojuoswiaty/ukrainska/9841,Monitorowanie-Strategii-rozwoju-swiaty-mniejszosci-ukrainskiej-w-Polsce.html

16. Nijakowski L., Oświata mniejszości narodowych w Polsce, http://zielonewiadomosci.pl/tematy/mniejszosci/oswiata-mniejszosci-narodowych-w-polsce

17. Olszański T.A., Problem językowy na Ukrainie: próba nowego spojrzenia, Warszawa 2012.

18. PAP, Polskie szkoty na Ukrainie: brak pieniędzy na podręczniki i pensje nauczycieli, http://www.oswiata.abc.com.pl/czytaj/-/artykul/polskie-szkoly-na-ukrainie-brak-pieniedzy-na-podreczniki-i-pensje-nauczycieli.

19. Paszkiewicz H., Początek Rusi, Kraków 1996. 
20. Polskie Szkoły na Ukrainie i Białorusi, Rozdział I Polityka Polski i Ukrainy wobec polskiej mniejszości narodowej na Ukrainie, http://polskieszkoly.org/ artykuly/5/ROZDZIAL-I-POLITYKA-POLSKI-I-UKRAINY-WOBEC-POLSKIEJ-MNIEJSZOSCI-NARODOWEJ-NA-UKRAINIE.html.

21. Portal Zjednoczenia Nauczycieli Polskich na Ukrainie Edukator, Lista szkót, http://polacy.info.pl/pl/lista-szkol.

22. Potapenko K., Cudzoziemcy i mniejszości narodowe na Ukrainie $i$ w Polsce, http://www.allerhand.pl/docs/granty/Mniejszosci_narodowe_na_Ukrainie_i_w_Polsce-raport_PL.pdf.

23. Ridna Mowa, Problemy oświaty, http://www.interklasa.pl/portal/dokumenty/ ridna_mowa_pl/index.php?page=podstawa-programowa, [dostęp: 21.02.2016].

24. Sierakowa J., Stan obecny i perspektywy szkolnictwa polskiego na Ukrainie [w:] Język polski w ukraińskiej edukacji-perspektywy $w$ aspekcie integracji europejskiej, Warszawa 2014.

25. Stowarzyszenia „Wspólnota Polska”, Polacy na Ukrainie - wg spisu ludności w 2001 r., http://wspolnotapolska.org.pl/polonia_w_opracowaniach/20.html.

26. Wątróbski L., O nauce języka polskiego na Ukrainie, http://polscott24.com/ polskie-szkolnictwo-na-ukrainie.

27. Zona zakona, Ustawa Ukraińskiej Socjalistycznej Republiki Radzieckiej O językach w Ukraińskiej SRR (z późniejszymi zmianami) z dnia 22 października 1989 r.; Fragmenty [w:] Wybór dokumentów prawnych..., s. 36-39, Закон СССР от 05.03.1991 N 1999-1. О внесении изменений и признании утратившими силу законодательных актов Союза ССР в связи с Законом СССР „О языках народов СССР”, http://www.zonazakona.ru/law/docs ussr/435/, [dostęp: 25.03.2016].

28. Związek Polaków na Ukrainie, Matura z polskiego wróciła na listę przedmiotów maturalnych na Ukrainie!, http://z-p-u.org/index.php/2016/05/30/ matura-z-polskiego-wrocila-na-liste-przedmiotow-maturalnych-na-ukrainie. 